\title{
Serum Adipocytokines, Metabolic and Immunological Correlations in Type 1 Diabetes mellitus (T1DM) Children
}

\author{
Ebtesam, A. AL-Suhaimi*, ${ }^{*}$, Fadwa, M. AL-Kulaifi ${ }^{1}$, Vijaya Ravinayagam ${ }^{2}$ and \\ Mohammad H. Al-Qahtani ${ }^{3}$ \\ ${ }^{1}$ Biology Department, College of Science, University of Dammam, Saudi Arabia \\ ${ }^{2}$ Department of Pathology, Dr. ALM Post Graduate Institute of Basic Medical Sciences, University of Madras, \\ Taramani campus, Chennai, Tamilnadu 600113, India \\ ${ }^{3}$ Pediatrics Department, College of Medicine, University of Dammam, Saudi Arabia
}

\begin{abstract}
The prevalence of childhood type 1 diabetes mellitus (T1DM) is high among Saudi Arabian population. A viable solution is imperative for combating dreadful endocrine based diseases using adipocytokines functional characters. A relation between, adipocytokines, metabolism and immunological indices of healthy and T1DM insulin treated Saudi children is evaluated. The target group was Saudi children healthy and insulin treated T1DM aged between 3 to 14 years. A total of 28 Saudi pediatric volunteers consist of 13 diabetic and 15 healthy have participated from King Fahad Teaching Hospital in Alkhobar city. Inclusion criteria of insulin treated T1DM participants should be free from hypertension, obesity, history of cardiac, kidney or liver disease and endocrine dysfunction except diabetes. Healthy children free from all these problems were included. Serum adipocytokines (leptin, adiponectin, apelin, visfatin, resistin), metabolic parameters (insulin, fasting glucose, $\mathrm{HbA1c}$ ) immunological indices (IgG, IgA, IgM, and IgE) and complement factors $(C 3$, C4) were assayed. Serum levels of leptin, apelin and visfatin were significantly elevated in T1DM treated with insulin group compared to healthy group. There is a positive correlation between adipocytokines and metabolic parameters but there is not with immunological indices. There was a significant positive correlation exists between HbA1c, glucose, leptin, apelin and insulin. Some elevated adipocytokines (leptin, visfatin and apelin) in serum may be attributed to the higher levels of HbA1c, glucose and insulin. Exogenous insulin treatment on T1DM children failed to control serum levels of adipocytokines (leptin, visfatin, apelin) and metabolic parameters (HbA1c, fasting glucose). The results revealed that leptin, visfatin and apelin may have a promising role as biomarkers in T1DM.
\end{abstract}

Keywords: Adiponectin, apelin, complement factors, glucose, HbA1c, immunoglobulins, leptin, resistin, visfatin.

\section{INTRODUCTION}

Type 1 Diabetes Mellitus (T1DM) is the most common chronic metabolic autoimmune disease [1]. It is characterized by hyperglycemia due to the infiltration of lymphocytes in the pancreas causing destruction of insulinproducing beta-cells [2, 3]. The incidence of T1DM is reported to be increasing by $3-5 \%$ per year, and the number of people with diabetes is estimated to reach 380 million by 2025 [4]. The incidence rate of childhood T1DM is increasing dramatically in many countries over the past 20 years [5]. A community based survey in Kingdom of Saudi Arabia (KSA) reported that the prevalence of T1DM below the age of 19 year to be 109 per 100000 [6]. The major cause of TIDM is attributed to changes in their habitual lifestyle represents a major clinical and public health problem $[7,8]$.

*Address correspondence to this author at the Biology Department, College of Science University of Dammam, Saudi Arabia; Tel: 0096638150917 Fax: 0096638150897; E-mail: ealsuhaimi@ud.edu.sa
To date there is no definitively proven therapies that can stop the progressive beta-cell defect and the progression of the metabolic disorder. Diabetes reduces the average life span with expensive treatment that is projected to cost USD 490 billion in 2030. More prevention efforts are needed to reduce the expenditure burden to provide basic diabetes care [9].

Since 1994, after the Diabetes Control and Complication Trial (DCCT), the use of insulin analoges in intensive regimen i.e. multiple daily doses or insulin pump therapy had improved the metabolic control and reduce the chronic complication of T1DM significantly [10]. However, current insulin treatments are far from satisfactory levels of metabolic control and protection from the long-standing complication of TIDM [11].

Several studies have shown that TIDM is associated with metabolic abnormalities, and alteration of adipose tissue hormones (adipocytokines or adipokines) and immunoglobulins [12-14]. T1DM in children is characterized by progressive loss of glucose homeostasis due to defects in insulin secretion resulting in impaired metabolism of glucose 
and other energy yielding fuels [15]. Glucose concentrations rise due to lack of insulin-stimulated glucose disappearance, and suppression of glucose utilization in skeletal muscle and adipose tissue [2]. The excess glucose present in the blood reacts with hemoglobin to form glycated hemoglobin (HbAlc) in a non-enzymatic glycation pathway [16]. Recently, $\mathrm{HbA} 1 \mathrm{c}$ as introduced was an additional diagnostic criteria for diabetes and pre-diabetes [17]. Although insulin is a hormone that plays a key role in the homeostasis of circulatory glucose [18], adipocytokines (soluble factors) which are secreted from adipose tissue, such as adiponectin, leptin, resistin, visfatin and apelin [12] have been implicated in the development of insulin resistance.

Leptin and adiponectin altered secretion or sensitivity have been extensively studied with T1DM. Leptin plays a major role in regulating energy metabolism in humans [19]. A significant relationship between leptin and insulin has been reported by Szalecki et al. [20]. Adiponectin possesses an effective insulin-sensitizing with anti-diabetic effect [21]. The elevated level of circulating adiponectin appears to be linked with long diabetes duration, irrespective of the metabolic control in TIDM [22]. Apelin is a novel adipocytokine that binds the APJ receptor. The synthesis and secretion of apelin tends to be regulated by insulin [23, 24]. However, so far the relation between apelin and TIDM has been scarcely reported. Resistin, a secretory protein is detected in human plasma. High level of resistin leads to impaired glucose tolerance and insulin action. Immunoneutralization of resistin was found to enhance insulin sensitivity in TIDM patients [25, 26]. Visfatin is a recently described adipokine that mimics insulin properties [27]. Visfatin gene mutation in mice results glucose intolerance primarily due to insulin secretion deficiency [28]. Erik et al. [29] found that blood visfatin may not be a useful clinical biomarker of metabolic traits. But Pfützner et al. [30] reported that visfatin is an assumed biomarker for metabolic disorders, also the pancreatic $\beta$-cell may be exposed to elevated visfatin levels, which can be used as specific markers for insulin sensitivity [31]. Recently, visfatin as a biomarker can be correlated with maternal factors to facilitate the early screening for Gestational diabetes mellitus (GDM)[32].

\section{AIM OF THE STUDY}

The aim of this study is to measure the adipocytokines serum levels and evaluate their relation to metabolic and immune parameters in treated T1DM Saudi children compared to healthy age and sex matching children.

\section{MATERIALS AND METHODS}

\section{Study Design and Target Patients}

The target groups were Saudi children healthy and diabetic treated with insulin. They have been followed at King Fahad Hospital of the University of Dammam (KFHU) in Alkhobar city, Saudi Arabia. A consent from all participant or/and their parents was obtained before the study. The research was approved by Ethics Committee of Biological and Medical Research for University of Dammam. No (HAP-05-D-003).

\section{Medical History}

A total of 28 Saudi pediatric subjects (3-14 years) were divided into two groups consisting of T1DM treated with insulin for at least 2 years $(n=13)$ and healthy participants $(n=15)$. The two groups were matched for both age and sex. This study has several limitations because of the narrow selection criteria, the sample size was small. Hence, our data may not be representative for all subjects with T1DM.

The inclusion criteria include kids having no hypertension, cardiac, renal, nor hepatic disease and no other endocrine dysfunction except diabetes. All of them were not obese; Body Mass Index (BMI) values were (15.4 - 20.2) $\mathrm{kg} / \mathrm{m}^{2}$ with normal height. Weight ranged $(19-47.5 \mathrm{~kg})$

\section{Blood Sample and Biochemical Assessment}

Fasting blood samples were collected in hospital lab. It was ensured that the participants were fasting for at least 12 hours. The last dose of insulin was 12 hours back. All patients receive regular insulin and (normal pressure hydrocephalus (NPH)) with average total dose of 0.8 $\mathrm{u} / \mathrm{kg} /$ day range of (0.6-1.0). The study tools included blood biochemical tests collected in non- heparinized test tubes, then centrifuged to separate the serum and saved at $-18{ }^{\circ} \mathrm{C}$ in deep freezer for the following assay:

Fasting serum glucose and Blood $\mathrm{HbAlc}$ were measured, using SIEMENS streem lab - Dimension clinical chemistry system-RXL max (USA), kits from SIEMENS. Leptin, adiponectin, apelin, visfatin and resistin were measured using the sandwich enzyme-linked immunosorbent assay (ELISA) by PHOENIX PHARMACEUTICALS, USA. Insulin was measured in serum using the ABBOT AxSYM SYSTEM produced by Axis-Shield Diagnostics, Ltd., Dundee, UK for Abbot Diagnostic Division 2009. The $\left(0.016 \%\right.$ at $\left.10^{6} \mathrm{pg} / \mathrm{Ml}\right)$. Immunoparameterswere measured in serum using BN proSpec System Produced by SIEMENS

\section{Statistical Analysis}

Data were analyzed using SPSS software version 19. A $t$ test was carried out to compare means of the healthy and T1DM treated children. Pearson correlation test was done to find the correlation between the assessed parameters. The result was expressed as mean \pm standard error of mean. Statistical significance was considered at the level of $(\mathrm{p}<0.01)$ and $(\mathrm{p}<0.05)$.

\section{RESULTS AND DISCUSSION}

\section{Adipocytokines Relationship with Fasting Glucose, HbA1c and Insulin in Pediatric}

Table 1 showed that the serum level of adipocytokines such as leptin was $(p<0.01)$ significantly elevated $(87.47 \pm 14.10 \mathrm{ng} / \mathrm{ml})$ in insulin treated $\mathrm{T} 1 \mathrm{DM}$ when compared with healthy control group $(24.85 \pm 11.29 \mathrm{ng} / \mathrm{ml})$. The observed result could be explained by Szalecki et al. [20]. Leptin plays an important role in maintaining body energy balance, while insulin plays a key role in leptin secretion and regulation [33]. In experimental study, insulin treatment acutely increased both secretion and production of leptin from adipose cells by a mechanism that is distinct 
from the release of stored secretory vesicles [34]. These were corroborated in the present clinical study with an increased serum leptin levels in insulin treated T1DM children. A rapid elevation in leptin after $24 \mathrm{~h}$ of insulinization was noticed and there was a stimulatory effect of insulin on leptin production in T1DM [35]. The increased serum leptin level was positively correlated with insulin therapy [36]. As shown in Table 2 , in the present study serum leptin level has apositive significant correlation $(\mathrm{p}<0.05)$ with serum fasting glucose concentration. It may be due to the inability of insulin and leptin to control serum fasting glucose level in T1DM treated with insulin children's. In addition, interestingly, it revealed that during insulin treatment leptin correlated positively with highly significant $(p<0.01)$ with, resistin, visfatin, apelin, and $\mathrm{HbA} 1 \mathrm{c}$.

Adiponectin is a unique adipokine that influences insulinsensitizing action [37]. Several studies reported that T1DM patients have significantly higher circulating adiponectin levels as compared to healthy individuals [38, 39]. It has also been suggested that insulin treatment negatively regulated the expression levels of adiponectin and insulin sensitivity in plasma and muscle $[40,41]$. In comparison to earlier reports our result of serum adiponectin levels of T1DM children did not increase when compared with healthy children (Table 1). The unchanged level of adiponectin may be due to insulin treatment. Table 2 showed that adiponectin has a positive significant $(\mathrm{p}<0.05)$ correlation with resistin during T1DM treatment with insulin in children.

Resistin influences insulin resistance, fasting glucose homeostasis, diabetes, and inflammation. The role of resistin in glycemia, insulin resistance, obesity is still debated. Human resistin level is elevated in TIDM condition [25]. In the present study, no differences in serum resistin levels were found between healthy control and TIDM insulin

Table 1. Serum Concentration of Adipocytokines, Metabolic Parameters, Immunoglobulins and Complement Factors in Healthy and T1DM Treated Children

\begin{tabular}{|c|c|c|}
\hline & \multicolumn{2}{|c|}{ Groups } \\
\hline & Healthy Children & Insulin Treated T1DM Children \\
\hline Leptin (ng/ml) & $24.85 \pm 11.29$ & $87.47 \pm 14.10^{* *}$ \\
\hline Adiponectin (ng/ml) & $12.11 \pm 1.97$ & $7.67 \pm 0.87$ \\
\hline Resistin (ng/ml) & $4.27 \pm 1.04$ & $5.55 \pm 0.59$ \\
\hline Visfatin (ng/ml) & $6.08 \pm 1.28$ & $9.79 \pm 1.02 *$ \\
\hline Apelin (ng/ml) & $1.28 \pm 0.12$ & $1.89 \pm 0.10^{* *}$ \\
\hline $\mathrm{HbAlc}(\%)$ & $5.54 \pm 0.11$ & $11.05 \pm 0.56^{* *}$ \\
\hline Glucose (mg/dl) & $94.00 \pm 4.78$ & $248.23 \pm 33.91^{* *}$ \\
\hline Insulin $(\mathrm{Uu} / \mathrm{ml})$ & $14.59 \pm 3.62$ & $55.10 \pm 14.59 *$ \\
\hline $\operatorname{IgM}(\mathrm{mg} / \mathrm{dl})$ & $122.06 \pm 10.15$ & $125.26 \pm 10.27$ \\
\hline $\operatorname{IgE}(\mathrm{IU} / \mathrm{ml})$ & $191.94 \pm 56.92$ & $77.23 \pm 19.15$ \\
\hline $\operatorname{IgA}(\mathrm{mg} / \mathrm{dl})$ & $174.52 \pm 17.56$ & $165.53 \pm 16.02$ \\
\hline $\operatorname{IgG}(\mathrm{mg} / \mathrm{dl})$ & $1304.80 \pm 90.85$ & $1219.69 \pm 37.05$ \\
\hline $\mathrm{C} 3(\mathrm{mg} / \mathrm{dl})$ & $145.5067 \pm 8.80$ & $148.2308 \pm 9.38$ \\
\hline $\mathrm{C} 4(\mathrm{mg} / \mathrm{dl})$ & $28.3067 \pm 3.48$ & $32.6231 \pm 3.42$ \\
\hline
\end{tabular}

Data indicate mean \pm SE

$* *$ Represent a significant difference with the healthy group at $\mathrm{P}<0.01$.

* Represent a significant difference with the healthy group at $\mathrm{P}<0.05$.

Table 2. Pearson Correlation Test of Studied Parameters in Children Serum

\begin{tabular}{|c|c|c|c|c|c|c|c|c|}
\hline & Leptin & Adiponectin & Resistin & Visfatin & Apelin & HbA1c & Glucose & Insulin \\
\hline Adiponectin & - & - & ${ }^{\star} .386$ & - & - & - & - & - \\
\hline Resistin & ${ }^{* *} .487$ & ${ }^{\star} .386$ & - & - & ${ }^{* *} .567$ & - & - & - \\
\hline Visfatin & ${ }^{* *} .861$ & - & $* \star .567$ & - & ** .798 & - & - & - \\
\hline
\end{tabular}

Data indicate mean \pm SE

$* *$ Correlation is significant at the $\mathrm{P}<0.01$ level and $*$ at the $\mathrm{P}<0.05$ level ( 2 - tailed). 
treated kids (Table 1). Earlier literatures have shown the average concentration of resistin was in the range between 5$10 \mathrm{ng} / \mathrm{ml}$ [42-44]. Our results commensurate with the normal range, which implied that it was not involved in metabolic changes in T1DM insulin treated children. It may be due to the restoration of resistin in T1DM condition due to insulin treatment. Table 2 showed that resistin positively correlates highly significant $(\mathrm{p}<0.01)$ with leptin, apelin and adiponectin $(\mathrm{p}<0.05)$.

The apelin synthesis and gene expression was reported to be upregulated by insulin [45]. Apelin tends to be related closely with insulin resistance and fasting glucose metabolism [46, 47]. Meral et al. [24] reported that plasma apelin was increased in children with T1DM. In this study (Table 1), we observed serum apelin levels were significantly $(\mathrm{p}<0.01$ higher in the T1DM insulin treated group (1.89 \pm 0.10$)$ compared to healthy controls $(1.28 \pm 0.12)$. Such elevations have direct positive correlation between serum apelin and insulin levels which might be due to insulin treatment. Table 2 showed that apelin positively correlated highly significantly $(p<0.01)$ with leptin, resistin, visfatin and significantly $(\mathrm{p}<0.05)$ with $\mathrm{HbA} 1 \mathrm{c}$ and insulin.

Visfatin is a recently discovered adipokine that has a primary role in regulation of insulin secretion in pancreatic $\beta$-cell. Toruner et al. [48] reported a lower level of visfatin in T1DM than controls with significant correlation between visfatin and HbAlc. On the contrary, in the present study, visfatin levels were significantly $(p<0.05)$ elevated in TIDM insulin treated than healthy control. No correlation between HbAlc and visfatin levels was observed. The results coincided with a beta -cell dysfunction mechanism linked between increased serum visfatin and T1DM $[49,50]$. It may be due to $\beta$-cell deterioration not restored by insulin treatment, which can be used as specific markers for insulin sensitivity [31]. It was reported that new insulin treatment mimics insulin secretion in the imperfection way [51]. Table 2 showed that visfatin positively correlated highly significantly $(\mathrm{p}<0.05)$ with leptin, resistin and apelin.

$\mathrm{HbA} 1 \mathrm{c}$ determines the fasting glucose concentration in diabetic patients and therefore reflects detrimental diabetic complications [52]. HbAlc levels were elevated in T1DM treated with insulin due to poor glycemic control [53]. As shown in Table 1, HbAlc increased highly significantly $(p<0.01) \quad(11.05 \quad \pm 0.56) \%$ in diabetic children when compared with control level $(5.54 \pm 0.11)$. The present data showed inability of regulating blood fasting glucose level in T1DM treated with insulin children. The current results coincided with the result of Soliman et al. [54] who reported a positive correlation between $\mathrm{HbAlc}$ level and leptin concentration. The higher serum levels of some adipocytokines in T1DM patients in present study may be attributed to associated high significant level of $\mathrm{HbAlc}$ (Tables 1 and 2). Insulin (exogenous) level may be the most important marker of leptin level. This can be partially explained with an increased appetite due to over substitution by insulin that contribute to increase leptin secretion and explained the higher leptin levels in diabetic children [55]. Table 3 revealed a highly significant positive correlation at the level $(p<0.01)$ between HbAlc with fasting glucose and insulin. It may be due to the poor control of glycemic regulation by exogenous insulin treatment.

Insulin has many metabolic functions [56-58]. During dysfunction in TIDM patients, insulin secretion fails in pancreas beta cells leading to metabolic disturbances. In our study, the insulin level increased significantly $(\mathrm{p}<0.05)$ in T1DM insulin treated children $(55.10 \pm 14.59) \mathrm{ng} / \mathrm{ml}$, when compared with healthy control $(14.59 \pm 3.62) \mathrm{ng} / \mathrm{ml}$. Table 3 represents a highly significant positive correlation at the $(\mathrm{p}<$ 0.01 ) level of insulin with HbAlc. It may be attributed to elevated leptin, visfatin and apelin due to failure of exogenous insulin treatment in T1DM treated with insulin patients.

Table 1 showed a significant increase of fasting glucose, HbA1c $(p<0.01)$ and insulin $(p<0.05)$ inT1DM treated with insulin than healthy control. In addition, Table $\mathbf{2}$ showed that there was a positive significant correlation of leptin with fasting glucose and HbAlc $(\mathrm{p}<0.05$ and $\mathrm{p}<$ 0.01 ). Table 3 also revealed that $\mathrm{HbAlc}$ has a positive significant correlation with fasting glucose and insulin. This correlation indicated that leptin is the most important adipokine, which synchronized with high fasting glucose concentration in target Saudi patient who had high ratio of $\mathrm{HbA1c}$ and insulin. This is in agreement with Ashraf et al. [59] who reported that over substitution by insulin exerted many metabolic actions and contribute in elevation of leptin release. They attributed the higher leptin levels in uncontrolled childhood diabetic (higher circulating HbAlc concentrations) that they were treated with insulin.

\section{Metabolic and Immune Parameters Relationship in Pediatric}

Immune parameters were assessed in T1DM treated with insulin and control healthy group. Complement $\mathrm{C} 3$ and $\mathrm{C} 4$ are the major plasma proteins of the immune system complement pathways. The synthesis of serum complement protein $\mathrm{C} 3$ increased in response to inflammation and metabolic disorders, diabetes $\mathrm{C} 3$ levels elevated in T1DM

Table 3. Pearson Correlation test for Metabolic Parameters and Immunoglobulins and Complement Factors

\begin{tabular}{|c|c|c|c|c|c|c|c|c|}
\hline & HbA1C & Glucose & Insulin & IgM & IgE & IgA & IgG & C3 \\
\hline \hline HbA1C & - & ${ }^{* *} .663$ & ${ }^{* *} .518$ & - & - & - & - & - \\
\hline Glucose & ${ }^{* *} .663$ & - & & - & - & - & - & - \\
\hline Insulin & ${ }^{* *} .518$ & & & - & - & - & - & - \\
\hline
\end{tabular}

** Correlation is significant at the $\mathrm{P}<0.01$ level $(2$ - tailed). 
[60,61]. Zhain et al. [62] reported that serum C3 and C4 of T1DM patients is significantly lower than corresponding value of healthy subjects and the lowest value of $\mathrm{C} 3$ was observed in patients with HbA1c $>11 \%$. The C3 levels were tended to reduce after improving glycaemia. Insulin has potential anti-inflammatory effects [63]. Insulin closely related with $\mathrm{C} 3$ and plays a vital role in alteration of fasting glucose metabolism [64]. Plasma levels of C3 and C4 were normal during insulin treatment in type 1 diabetes, our results were in agreement with the report of Rego Filho et al. [65] where the levels of complement factors $\mathrm{C} 3, \mathrm{C} 4$ and immunoglobulins IgG, IgA, IgE, IgM in T1DM group didn't change compare with healthy control (Table 1).

T1DM patients have shown elevated plasma levels of $\operatorname{IgM}$ and $\operatorname{IgA}$, and a reduced level of $\operatorname{IgG}$ compared to healthy controls [66]. Immunological complications have decreased significantly showing a prolonged restoration of $\beta$ cell function in T1DM insulin treated patient [67]. Earlier findings showed that $T$ cells played adverse role in $\beta$-cell destruction in T1DM. Exogenous insulin treatment was used to stimulate activation of insulin-specific T-cell for subsequent restoration action in T1DM patients [68]. IgG and IgE are reported to be interrelated in T1DM condition [69]. In our data, IgE and IgG levels in T1DM patients were not change significantly compared with healthy children (Table 1). However, in between $\operatorname{IgE}$ and $\mathrm{IgG}$, a highly significant $(\mathrm{p}<0.01)$ correlations was observed. No significant changes in IgA, C3 and C4 observed in T1DM treated with insulin and healthy children (Table 1). Notably, IgA was found to be positively correlated with $\mathrm{C} 3$ and $\mathrm{C} 4$ at the $(\mathrm{P}<0.01)$ level. Previous studies found a change with plasma levels of IgA, C3 and C4 which was reported to be associated with insulin treatment [70, 71]. Interestingly, Pearson test revealed that there was no correlation exists between adipocytokines with immunoglobulins and complement factor $\mathrm{C} 3$ and $\mathrm{C} 4$. It showed that insulin treatment in T1DM patients might regulate complement factors and immunoglobulins but not the disturbed adipocytokines (leptin, visfatin and apelin).

\section{CONCLUSION}

- Leptin was the most important adipocytokine, where its high level was synchronized with high fasting glucose concentration in insulin treated T1DM patients who had high $\mathrm{HbA} 1 \mathrm{c}$ and insulin level.

- Insulin treated T1DM children had significantly elevated serum level of leptin, apelin, visfatin, $\mathrm{HbA1C}$, fasting glucose and insulin but showed near normal levels of adiponectin and resistin when compared with healthy children.

- Serum immunoglobulins and complement factors $(\mathrm{C} 3, \mathrm{C} 4)$ levels of T1DM treated with insulin were found to near normal levels comparable to healthy children with no correlation with the adipocytokines.

Finally it could be suggested that serum leptin, visfatin and apelin appear to have a promising role as biomarkers in T1DM, the ability to regulate them in these patients was needed in further studies to help in managing this disorder.

\section{CONFLICT OF INTEREST}

The authors confirm that this article content has no conflict of interest.

\section{ACKNOWLEDGEMENTS}

This study is a part of a research project funded by King Abdulaziz City for Science and Technology (KACST) NO. A-S-12- 0909

\section{REFERENCES}

[1] Shulman RM, Daneman D. Type 1 diabetes mellitus in childhood. Medicine 2010; 38: 679-85.

[2] Atkinson MA, Maclaren N. The pathogenesis of insulin-dependent diabetes mellitus. N Engl J Med 1994; 331: 1428-36.

[3] Waldron-Lynch F, Herold KC. Immunomodulatory therapy to preserve pancreatic $\beta$-cell function in type 1 diabetes. Nat Rev Drug Discov 2011; 10: 439-52.

[4] International Diabetes Federation. Diabetes Atlas. $3^{\text {rd }}$ ed. Brussels: International Diabetes Federation 2006.

[5] Berhan Y, Waernbaum I, Lind T, Möllsten A, Dahlquist G. Thirty years of prospective nationwide incidence of childhood type 1 diabetes: the accelerating increase by time tends to level off in Sweden. Diabetes 2011; 60: 577-81.

[6] Al-Herbish AS, El-Mouzan MI, Al-Salloum AA, Al-Qurachi MM, Al-Omar AA. Prevalence of type 1 diabetes mellitus in Saudi Arabian children and adolescents. Saudi Med J 2008; 29: 1285-8.

[7] Abduljabbar MA, Aljubeh JM, Amalraj A, Cherian MP. Incidence trends of childhood type 1 diabetes in eastern Saudi Arabia. Saudi Med J 2010; 31: 413-8.

[8] Washi SA, Ageib MB. Poor diet quality and food habits are related to impaired nutritional status in 13- to 18-year-old adolescents in Jeddah. Nutr Res 2010; 30: 527-34.

[9] Zhang P, Zhang X, Brown J, Vistisen D, Sicree R, Shaw J \& Nichols G. Global healthcare expenditure on diabetes for 2010 and 2030. Diabetes Res Clin Pract 2010; 87: 293-301.

[10] Nathan DM, Cleary PA, Backlund JY et al. Intensive diabetes treatment and cardiovascular disease in patients with type 1 diabetes. N Engl J Med 2005; 353: 2643-53.

[11] Agrawal RP, Beniwal R, Sharma S, Kochar DK, Tuteja FC, Ghorui SK, Sahani MS. Effect of raw camel milk in type 1 diabetic patients: 1 year randomized study. J Camel Pract Res 2005; 12: 2735 .

[12] Bulcão C, Ferreira SR, Giuffrida FM, Ribeiro-Filho FF. The new adipose tissue and adipocytokines. Curr Diabetes Rev 2006; 2: 19 28.

[13] Sosenko JM, Palmer JP, Greenbaum CJ, et al. Patterns of metabolic progression to type 1 diabetes in the Diabetes Prevention TrialType 1. Diabetes Care 2006; 29: 643-9.

[14] Svensson J, Eising S, Mortensen HB, et al. Danish Childhood Diabetes Registry. High levels of immunoglobulin $\mathrm{E}$ and a continuous increase in immunoglobulin $\mathrm{G}$ and immunoglobulin $\mathrm{M}$ by age in children with newly diagnosed type 1 diabetes. Hum Immunol 2012; 73: 17-25.

[15] Mealey BL, Ocampo GL. Diabetes mellitus and periodontal disease. Periodontology 2007; 44: 127-53.

[16] Larsen ML, Hørder M, Mogensen EF. Effect of long-term monitoring of glycosylated hemoglobin levels in insulin-dependent diabetes mellitus. N Engl J Med 1990; 323: 1021-5.

[17] Veeranna V, Ramesh K, Zalawadiya SK, Niraj A, Pradhan J, Jacob $\mathrm{S}$, Afonso L. Glycosylated hemoglobin and prevalent metabolic syndrome in nondiabetic multiethnic U.S. adults. Metab Syndr Relat Disord 2011; 9: 361-7.

[18] Lehninger, A. L. Biochemistry. $2^{\text {nd }}$ ed. Ludhiana, New Delhi: Kalyani Publishers 1978; p. 820.

[19] Montague CT, Farooqi IS, Whitehead JP, et al. Congenital leptin deficiency is associated with severe early-onset obesity in humans. Nature 1997; 387: 903-8.

[20] Szalecki M, Pańkowska E, Wysocka-Mincewicz M, Klupa T, Janas R. Leptin and soluble leptin receptor in children with type 1 diabetes mellitus. Pediatr Endocrinol Diabetes Metab 2010; 16: 262-9. 
[21] Pyrzak B, Ruminska M, Popko K, Demkow U. Adiponectin as a biomarker of the metabolic syndrome in children and adolescents, Eur J Med Res 2010; 15: 147-51.

[22] Lindström T, Frystyk J, Hedman CA, Flyvbjerg A, Arnqvist HJ. Elevated circulating adiponectin in type 1 diabetes is associated with long diabetes duration. Clin Endocrinol (Oxf) 2006; 65: 77682.

[23] Szokodi I, Tavi P, Földes G, et al. Apelin, the novel endogenous ligand of the orphan receptor APJ, regulates cardiac contractility. Circ Res 2002; 91: 434-40.

[24] Meral C, Tascilar E, Karademir F, et al. Elevated plasma levels of apelin in children with type 1 diabetes mellitus. J Pediatr Endocrinol Metab 2010; 23: 497-502.

[25] Fehmann HC, Heyn J. Plasma resistin levels in patients with type 1 and type 2 diabetes mellitus and in healthy controls. Horm Metab Res 2002; 34: 671-3.

[26] Shalev A, Patterson NB, Hirshberg B, Rother KI, Harlan DM. Resistin serum levels in type 1 diabetes pre- and post-islet transplantation. Metabolism 2004; 53: 403-4.

[27] Fukuhara A, Matsuda M, Nishizawa M, et al. Visfatin: a protein secreted by visceral fat that mimics the effects of insulin. Science 2005; 307: 426-30.

[28] Revollo JR, Körner A, Mills KF, et al. Nampt/PBEF/Visfatin regulates insulin secretion in beta cells as a systemic NAD biosynthetic enzyme. Cell Metab 2007; 6: 363-75.

[29] Ingelsson E, Larson MG, Fox CS, et al. Clinical Correlates of Circulating Visfatin Levels in a Community-Based Sample. Diabetes Care 2007; 30(5): 1278-80.

[30] Pfützner A, Hanefeld M, Lübben G, et al. Visfatin: a putative biomarker for metabolic syndrome is not influenced by pioglitazone or simvastatin treatment in nondiabetic patients at cardiovascular risk results from the PIOSTAT. Horm Metab Res 2007; 39 (10): 764-8.

[31] Taşçilar ME, Cekmez F, Meral C, et al. Evaluation of adipocytokines in obese children with insulin resistance. Turk J Pediatr 2011; 53: 269-73.

[32] Ferreira AFA, Rezende JC, Vaikousi E, Akolekar R, Nicolaides $\mathrm{KH}$. Maternal Serum Visfatin at 11-13 Weeks of Gestation in Gestational Diabetes Mellitus. Clin Chem 2011; 57(4): 609-13.

[33] Tucholski K, Otto-Buczkowska E. The role of leptin in the regulation of carbohydrate metabolism. Endokrynol Pol 2011; 62: 258-62.

[34] Barr VA, Malide D, Zarnowski MJ, Taylor SI, Cushman SW. Insulin stimulates both leptin secretion and production by rat white adipose tissue. Endocrinology 1997; 138: 4463-72.

[35] Hanaki K, Becker DJ, Arslanian SA. Leptin before and after insulin therapy in children with new-onset type 1 diabetes. J Clin Endocrinol Metab 1999; 84(5): 1524-6.

[36] Bideci A, Cinaz P, Ezgü FS. Leptin levels in children with insulin dependent diabetes mellitus. Turk J Pediatr 2002; 44: 211-4.

[37] Wang C, Mao X, Wang L, et al. Adiponectin sensitizes insulin signaling by reducing p70 S6 kinase-mediated serine phosphorylation of IRS-1. J Biol Chem 2007; 282: 7991-6.

[38] Perseghin G, Lattuada G, Danna M, et al. Insulin resistance, intramyocellular lipid content, and plasma adiponectin in patients with type 1 diabetes. Am J Physiol Endocrinol Metab 2003; 285: E1174-81.

[39] Maruyama C, Ishibashi R, Araki R, Koike S, Hirose H, Maruyama T. HMW-adiponectin associates with triglyceride concentrations in type 1 diabetic patients. J Atheroscler Thromb 2009; 16(3): 207-16.

[40] Sánchez-Gurmaches J, Cruz-Garcia L, Gutiérrez J, Navarro I. Adiponectin effects and gene expression in rainbow trout: an in vivo and in vitro approach. J Exp Biol 2012; 215: 1373-83.

[41] Tsuchida A, Yamauchi $\mathrm{T}$, Ito $\mathrm{Y}$, et al. Insulin/Foxo1 pathway regulates expression levels of adiponectin receptors and adiponectin sensitivity. J Biol Chem 2004; 279: 30817-22.

[42] Anderson PD, Mehta NN, Wolfe ML, et al. Innate immunity modulates adipokines in humans. J Clin Endocrinol Metab 2007; 92: 2272-9.

[43] Baker AR, Silva NF, Quinn DW, et al. Human epicardial adipose tissue expresses a pathogenic profile of adipocytokines in patients with cardiovascular disease. Cardiovasc Diabetol 2006; 5: 1-7.

[44] Lee SA, Kallianpur A, Xiang YB, et al. Intra-individual variation of plasma adipokine levels and utility of single measurement of these biomarkers in population-based studies. Cancer Epidemiol Biomarkers Prev 2007; 16: 2464-70.

[45] Carpéné C, Dray C, Attané C, et al. Expanding role for the apelin/APJ system in physiopathology. J Physiol Biochem 2007; 63: 359-73.

[46] Erdem G, Dogru T, Tasci I, Sonmez A, Tapan S. Low plasma apelin levels in newly diagnosed type 2 diabetes mellitus. Exp Clin Endocrinol Diabetes 2008; 116: 289-92.

[47] Dray C, Knauf C, Daviaud D, et al. Apelin stimulates glucose utilization in normal and obese insulin-resistant mice. Cell Metab 2008; 8: 437-45.

[48] Toruner F, Altinova AE, Bukan N, et al. Plasma visfatin concentrations in subjects with type 1 diabetes mellitus. Horm Res 2009; 72: 33-7.

[49] López-Bermejo A, Chico-Julià B, Fernàndez-Balsells $\mathrm{M}$, et al. Serum visfatin increases with progressive beta-cell deterioration. Diabetes 2006; 55: 2871-5.

[50] Stadler M, Storka A, Theuer EA, et al. Adipokines in type 1 diabetes after successful pancreas transplantation: normal visfatin and retinol-binding-protein-4, but increased total adiponectin fasting concentrations. Clin Endocrinol (Oxf) 2010; 72: 763-9.

[51] Bhatia E, Aggarwal A Insulin therapy for patients with type 1 diabetes. J Assoc Physicians India 2007; 55(29-34): 39-40.

[52] Castilho EM, Glass ML, Manço JC. The effects of 2,3diphosphoglycerate, adenosine triphosphate, and glycosylated hemoglobin on the hemoglobin-oxygen affinity of diabetic patients. Braz J Med Biol Res 2003; 36: 731-7.

[53] Nixon R, Pickup JC. Fear of hypoglycemia in type 1 diabetes managed by continuous subcutaneous insulin infusion: is it associated with poor glycemic control? Diabetes Technol Ther 2011; 13: 93-8.

[54] Soliman M, Ishioka K, Yoshida R, et al. Serum leptin levels during the periparturient period in cows. J Vet Med Sci 2002; 64: 1053-6.

[55] Muzumdar R, Ma X, Yang X, et al. Physiologic effect of leptin on insulin secretion is mediated mainly through central mechanisms. FASEB J 2003; 7: 1130-2.

[56] Kuzuya T, Nakagawa S, Satoh J, et al. Committee of the Japan Diabetes Society on the diagnostic criteria of diabetes mellitus. Report of the Committee on the classification and diagnostic criteria of diabetes mellitus. Diabetes Res Clin Pract 2002; 55: 6585.

[57] Ganong WF. Review of Medical Physiology. Lange Medical Books. ISBN: 0071402365. $21^{\text {st }}$ ed. USA: McGraw-Hill Medical Publishing Division 2003; pp. 433-6.

[58] Guyton AC, Hall JE. Ch. 78: Insulin, Glucagon, and Diabetes, In: Textbook of Medical Physiology. Guyton \& Hall, ELSEVIER SAUNDERS Publication. ISBN: 0-7216-0240-1. $11^{\text {th }}$ ed. 2006; pp. 961-70,

[59] Soliman AT, Omar M, Assem HM, et al. Serum leptin concentrations in children with type 1 diabetes mellitus: relationship to body mass index, insulin dose, and glycemic control. Metab Clin Exper 2002; 51(3): 292-6.

[60] McMillan DE. Elevation of complement components in diabetes mellitus. Diabetes Metab 1980; 6: 265-70.

[61] Krantz S, Stelter F, Lober M, Rjasanowski I, Michaelis D, Buske B. Complement component 3 (C 3 ) and diabetes mellitus. Exp Clin Endocrinol 1988; 92: 287-96.

[62] Dezayee ZMI, Alnakshabandi AA. Assessment of some immunological parametrs in respect to glycemic control in type 1 and 2 diabetes mellitus: Comparative study. Res J Med Sci 2011; 5(3): 119-21.

[63] Dandona P, Aljada A, Mohanty $\mathrm{P}$, et al. Insulin inhibits intranuclear nuclear factor kappaB and stimulates IkappaB in mononuclear cells in obese subjects: evidence for an antiinflammatory effect? J Clin Endocrinol Metab 2001; 86: 3257-65.

[64] Koistinen HA, Koivisto VA, Ebeling P. Serum complement protein C3 concentration is elevated in insulin resistance in obese men. Eur J Intern Med 2000; 11: 21-6.

[65] RegoFilho EA, Mello SF, Omuro AM, Loli JO. Simultaneous onset of steroid-sensitive nephrotic syndrome and type 1 diabetes. J Pediatr (Rio J) 2003; 79: 557-60.

[66] Gorus FK, Vandewalle CL, Winnock F, et al. Increased prevalence of abnormal immunoglobulin $\mathrm{M}, \mathrm{G}$, and $\mathrm{A}$ concentrations at clinical onset of insulin-dependent diabetes mellitus: a registry- 
based study. The Belgian Diabetes Registry. Pancreas1998; 16: 509.

[67] Tiittanen M, Huupponen JT, Knip M, Vaarala O. Insulin treatment in patients with type 1 diabetes induces upregulation of regulatory T-cell markers in peripheral blood mononuclear cells stimulated with insulin in vitro. Diabetes 2006; 55: 3446-54.

[68] Bruni B, Barolo P, Gadaleta G, GambaAnsaldi S, Grassi G, Zerbinati A, Molinatti M, Salvetti E. HLA typing and insulin antibody production in insulin-dependent diabetics, Ann Osp Maria Vittoria Torino 1984; 27: 185-213.
[69] Miller LL, Izzo MJ, Wemett D, Panner BJ, Schenk EA. Increased plasma IgA, sIgA, and C3- and IgA-containing immune complexes with renal glomerular deposits in diabetic rats. Diabetes 1988; 37: 185-93.

[70] Akinlade KS, Arinola OG, Salimonu LS, Oyeyinka GO Circulating immune complexes, immunoglobulin classes (IgG, IgA and $\mathrm{IgM})$ and complement components $(\mathrm{C} 3, \mathrm{C} 4$ and Factor B) in diabetic Nigerians. West Afr J Med 2004; 23: 253-5.

[71] Wang M, Chena L, Clarka GO, et al. Leptin therapy in insulindeficient type I diabetes. Proc Natl Acad Sci USA 2010; 107(11): 4793.

(C) AL-Suhaimi et al.; Licensee Bentham Open.

This is an open access article licensed under the terms of the Creative Commons Attribution Non-Commercial License (http://creativecommons.org/licenses/by$\mathrm{nc} / 3.0 /$ ) which permits unrestricted, non-commercial use, distribution and reproduction in any medium, provided the work is properly cited. 